\title{
MUTU ORGANOLEPTIK DAN KIMIAWI TERASI UDANG REBON DENGAN KADAR GARAM BERBEDA DAN LAMA FERMENTASI
}

\section{The Quality of Organoleptic and Chemically in Rebon Shrimp Paste to Different of Salt Concentration and Duration Fermentation}

\author{
Apri Dwi Anggo, Fronthea Swastawati`, Widodo Farid Ma'ruf, Laras Rianingsih \\ Program Studi Teknologi Hasil Perikanan Jurusan Perikanan Fakultas Perikanan dan Ilmu Kelautan \\ Universitas Diponegoro, Jalan Prof. Soedarto, SH. Kampus UNDIP Tembalang Semarang. \\ Telepon 024 7474698, Kode Pos 50275 \\ *Korespondensi: fronthea_thp@undip.ac.id \\ Diterima 17 Maret 2014/Disetujui 06 April 2014
}

\begin{abstract}
Abstrak
Terasi merupakan produk fermentasi udang dengan penambahan garam. Fermentasi dengan garam menyebabkan perombakan protein menjadi asam amino misalnya asam glutamat sebagai penghasil cita rasa khas terasi. Kadar garam dan lama fermentasi merupakan faktor penting pada proses pembuatan terasi. Penelitian ini bertujuan untuk menganalisis pengaruh perbedaan konsentrasi garam dan lama fermentasi terhadap kualitas terasi rebon terutama kandungan asam glutamat. Bahan baku yang digunakan pada penelitian ini adalah rebon (Acetes sp.) kering tawar dengan panjang $\pm 2 \mathrm{~cm}$ per ekor. Perlakuan garam dengan konsentrasi 2\%, 8,5\%, 15\% dan lama fermentasi ( 8 hari dan 32 hari). Metode penelitian menggunakan metode experimental field dengan Rancangan Acak Kelompok (RAK) pola split plot in time 3 kali ulangan. Parameter yang diuji meliputi organoleptik, $\mathrm{pH}$, kadar protein, asam glutamat, kadar air dan profil asam amino. Parameter kadar protein, asam glutamat dan profil asam amino pada fermentasi hari ke 32 yang diamati hanya perlakuan konsentrasi kadar garam terbaik pada hari ke 8 . Nilai organoleptik terasi berkisar antara 7,65-8,32 artinya produk tersebut dapat diterima konsumen. Nilai pH Nilai pH terasi rebon berkisar antara 7,09 sampai 7,89. Konsentrasi garam 2\% pada terasi rebon menghasilkan kadar protein dan asam glutamat tertinggi yaitu 47,14\%+0,20 (dry base). Asam amino yang dominan pada terasi rebon adalah asam glutamat dan asam aspartat. Lama fermentasi menyebabkan penurunan asam glutamat terasi rebon.
\end{abstract}

Kata kunci: asam glutamat, fermentasi, garam, rebon

\begin{abstract}
Terasi is a product of fermented shrimp paste with the addition of salt . Fermented with salt caused the changer protein into amino acids, for example glutamic acid is a produce of distinctive taste of shrimp paste. Salinity and fermentation time are the important factor in the process of making paste. This study aimed to analyze the effect of different salt concentration and fermentation time on the quality of shrimp paste rebon especially glutamic acid content. Raw material used in this study was (Acetes sp.) dried rebon with $\pm 2 \mathrm{~cm}$ long tail. The treatments are salt concentration of $2 \%, 8.5 \%, 15 \%$ and fermentation time (8 days and 32 days). The research using experimental methods with randomized block design (RBD ) pattern split plot in time 3 replications. The parameters included organoleptic, $\mathrm{pH}$, protein content, glutamic acid, moisture content and amino acid profile. Parameter levels of protein, glutamic acid and amino acid profiles in the fermentation day 32 were observed only the best concentration of salt treatment on day 8 . The organoleptic value ranged from 7.65 to 8.32 . It means the product was acceptable to consumers . PH value of small shrimp paste is from 7.09 to $7.89 .2 \%$ salt concentration on small shrimp paste produced levels of protein and glutamic acid highest $47.14+0.20 \%$ (dry base ). The dominant amino acids on small shrimp paste were glutamic acid and aspartic acid. Fermentation time caused a decrease in shrimp paste rebon glutamic acid .
\end{abstract}

Keywords: fermentation, glutamic acid, rebon 


\section{PENDAHULUAN}

Terasi adalah suatu jenis penyedap makanan berbentuk pasta, berbau khas hasil fermentasi udang, ikan, atau campuran keduanya dengan garam atau bahan tambahan lain. Hampir semua negara di Asia Selatan dan Tenggara memiliki produk ini yaitu Hentak, Ngari, dan Tungtap di India, Bagoong di Filipina, Terasi di Indonesia, Belacan di Malaysia, Ngapi di Myanmar, Ka-pi di Thailand. Pasta ikan atau udang biasanya terbuat dari berbagai jenis ikan air tawar dan laut serta udang (Thapa 2002).

Kandungan asam amino utama yang terdapat dalam fermentasi udang bergaram (terasi) selama penyimpanan 3 bulan adalah asam aspartat, asam glutamat, alanina, leusina, dan lisina. Sampel terasi dengan kandungan protein tertinggi merupakan terasi terbaik, karena komponen zat gizi yang mendukung kualitas terasi dapat dilihat dari tingginya kadar protein. Peralta et al. 2005 menyatakan bahwa asam amino yang diperoleh dari proses fermentasi garam melalui pemecahan komponen bahan baku oleh aktivitas enzim pendegradasi (misalnya protease, amilase, dan lipase) merupakan prekursor timbulnya rasa gurih (umami). Selama proses fermentasi ikan berlangsung, semakin besar produksi enzim dari mikroorganisme dapat menghasilkan pembentukan asam amino semakin tinggi oleh aktivitas enzim proteolitik, terutama asam glutamat dan asam aspartat (Susilowati 2010).

Asam glutamat dapat diperoleh dari glutamina. Asam glutamat termasuk asam amino non esensial yang bermuatan (polar) dan dapat diproduksi sendiri oleh tubuh manusia. Asam glutamat didalamnya terdapat ion glutamat sehingga dapat merangsang beberapa tipe saraf yang ada di lidah manusia. Sifat ini sering dimanfaatkan dalam industri penyedap rasa. Kadar asam glutamat yang tinggi pada terasi berpotensi sebagai komponen bumbu penyedap (Mouristen et al 2010).

Fungsi penambahan garam dalam proses fermentasi selain untuk pengawet, juga bertujuan untuk mendapatkan kondisi tertentu yang memungkinkan enzim atau mikroorganisme tahan garam (halotoleran) dapat bereaksi menghasilkan produk makanan dengan karakteristik tertentu. Proses fermentasi dapat juga dilakukan dengan bantuan enzim atau fermen yang berasal dari dalam tubuh ikan itu sendiri. Shahidi dan Botta (1994) menyatakan bahwa enzim protease endogenous atau golongan endopeptidase dapat berkontribusi dalam proses hidrolisis protein untuk makanan dan pakan hewan. Proses fermentasi terasi akan terjadi perubahan-perubahan fisik, kimiawi, dan mikrobiologi. Perubahan tersebut terjadi secara bersamaan dan paling dominan adalah perubahan kimiawi oleh enzim dari udang, rebon atau ikan itu sendiri, hal ini diduga bahwa kualitas terasi udang rebon dapat dipengaruhi oleh konsentrasi garam dan lama proses fermentasi untuk menghasilkan cita rasa produk yang diinginkan. Penambahan konsentrasi garam dan lama fermentasi dimungkinkan dapat mempengaruhi kualitas terasi yang dihasilkan. Penelitian ini bertujuan untuk menganalisis pengaruh perbedaan konsentrasi garam dan lama waktu fermentasi terhadap kualitas terasi rebon yang dihasilkan terutama asam glutamat.

\section{BAHAN DAN METODE}

\section{Bahan dan Alat}

Penelitian ini dilaksanakan pada bulan Juli-November 2013 di Desa Tambak Rejo, Kecamatan Semarang, Jawa Tengah. Bahan baku yang digunakan yaitu rebon (Acetes sp.) kering tawar dengan panjang $(0,5-3) \mathrm{cm} /$ ekor dan garam krosok. Alat yang digunakan pada penelitian ini meliputi glassware, moisture analyzer (MB45 Ohaus), pH meter, Kjehldal, dan score sheet organoleptik.

\section{Metode Penelitian}

Metode penelitian yang digunakan adalah experimental field yaitu penelitian dengan pembuatan produk dilakukan dalam skala industri kecil rumah tangga di Semarang. Pengujian organoleptik dan uji kimiawi dilakukan di Laboratorium Analisis Fakultas Perikanan dan Ilmu Kelautan, Universitas Diponegoro, Semarang. Profil asam amino dilakukan di PT. Saraswanti Indo Genetech Jakarta. Rancangan penelitian 
menggunakan RAK (Rancangan Acak Kelompok) pola Split Plot in Time dengan 3 kali ulangan. Perlakuan konsentrasi garam 2\%, 8,5\%, dan 15\% dan lama fermentasi yang digunakan adalah 8 hari dan 32 hari.

Prosedur pengolahan terasi berdasarkan Moeljanto (1992), yang telah dimodifikasi mengikuti proses pembuatan terasi skala industri rumah tangga di Semarang. Preparasi dilakukan dengan membersihkan rebon dari kotoran, kemudian dicampur secara merata dengan garam sesuai perlakuan. Adonan dimasukkan ke dalam alat penggilingan sedikit demi sedikit sambil dipercikan air agar adonan tidak menggumpal. Adonan giling kemudian diletakkan di atas widig atau alat penjemur untuk penjemuran pertama. Penjemuran dilakukan selama \pm 2 jam dengan sinar matahari. Pembalikan secara berulang selama penjemuran dilakukan supaya adonan kering merata. Adonan yang telah kering dimasukkan ke dalam baskom plastik sambil diangin-anginkan. Adonan daging rebon kemudian digiling kembali lalu dijemur lagiselama \pm 2 jam. Adonan yang sudah kering selanjutnya digilinglagi untukmenghasilkan adonan terasi yang halus dan kalis sehingga mempermudah proses pencetakan. Adonan terasi disimpan dalam baskom plastik dan ditutup tidak terlalu rapat. Terasi kemudian dieramkan pada suhu ruang selama 48 jam. Proses pemeraman ini bertujuan untuk melakukan fermentasi awal adonan terasi supaya menghasilkan aroma khas terasi, kemudian dicetak berbentuk seperti tabung dengan diameter $\pm 3 \mathrm{~cm}$ dan panjang $\pm 10 \mathrm{~cm}$ dengan berat per $100 \mathrm{~g}$. Potongan terasi diletakkan dalam nampan kemudian dijemur selama \pm 2 hari kemudian dibungkus rapat dengan daun pisang dan dieramkan. Sampel diuji pada hari ke-8 dan 32 (dihitung sejak bahan baku mulai digiling). Proses pembuatan terasi sudah selesai ketika bau khas terasi mulai tercium. Terasi diuji organoleptik, $\mathrm{pH}$, kadar protein, asam glutamat, kadar air dan profil asam amino. Kadar protein, asam glutamat dan profil asam amino pada fermentasi hari ke- 32 hanya diamati dari hasil terbaik penggunaan konsentrasi garam pada hari ke- 8 .

\section{Uji Organoleptik Terasi (BSN 2009)}

Pengujian organoleptik dilakukan oleh panelis semi terlatih sebanyak 30 orang dengan menilai sesuai spesifikasi yang ada dalam score sheet. Score sheet yang digunakan adalah score sheet terasi pasta udang mengacu pada SNI 01-2716-2009.

\section{Pengujian pH (AOAC 2005)}

Sampel sebanyak $5 \mathrm{~g}$ terasi dihaluskan dan ditambahkan akuades sebanyak $10 \mathrm{~mL}$. Sampel kemudian dimasukkan ke dalam beaker glass yang berisi larutan terasi. Titik akhir $\mathrm{pH}$ tercapai bila nilai $\mathrm{pH}$ meter konstan.

\section{Kadar Protein Metode Mikro-Kjeldhal (AOAC 1995)}

Analisis kadar protein diuji dengan mengukur kandungan nitrogen yang ada di dalam bahan makanan. Perhitungan kadar protein dilakukan dengan rumus:

$$
\begin{gathered}
\text { Nitrogen }(\%)=\frac{\mathrm{mL} \mathrm{HCl}-\mathrm{mL} \text { blanko }-\mathrm{N} \mathrm{HCl} \times 14,007}{m g \text { sampel }} \\
\text { \% kadar protein }=\% \text { nitrogen x 6,25 }
\end{gathered}
$$

\section{Uji Asam Glutamat (BSN 1995)}

Sampel sebanyak 0,1-0,2 g dimasukkan ke dalam labu Kjeldahl dan ditambahkan $5 \mathrm{~g}$ campuran selen dan $20 \mathrm{~mL}$ asam sulfat pekat teknis kemudian dipanaskan di dalam ruang asam, mula-mula dengan nyala kecil sambil digoyang-goyangkan. Api dibesarkan selama 5-10 menit dan terus dipanaskan hingga warna cairan menjadi hijau, didinginkan. Sampel dingin diencerkan dengan $50 \mathrm{~mL}$ air dan dipindahkan kedalam labu didih 250 mL. Sampel kemudian ditambahkan $40 \mathrm{~mL}$ $\mathrm{NaOH} 40 \%$ dan disambungkan dengan alat penyuling selama 50 menit dan hasil sulingan yang terdapat ditampung dengan $\mathrm{H}_{3} \mathrm{BO}_{3} 2 \%$ kemudian di titar dengan HCI 0,1 N kemudian dihitung menggunakan rumus:

Kadar Nitrogen $(\%)=\frac{\mathrm{v} \times \mathrm{N} \times 14}{\mathrm{q}} \times 100 \%=a \%$ 


$$
\text { Kadar Asam Glutamat }=\frac{147,1}{14} \times a \%
$$

Dimana:

$$
\begin{array}{ll}
\mathrm{V} & =\mathrm{mL} \mathrm{HCl} \\
\mathrm{N} & =\mathrm{HCl} 0,1 \mathrm{~N} \\
14 & =\text { bobot atom nitrogen } \\
147,1 & =\text { bobot molekul asam glutamat } \\
\mathrm{q} & =\text { mg contoh }
\end{array}
$$

\section{Kadar air menggunakan Moisture Analyzer MB45 Ohaus (AOAC 2007)}

Target weight yang digunakan sebesar 2 g. sampel kosong ke dalam tempat sampel, dilanjutkan dengan memasukkan sampel sesuai target weight, tutup, kemudian ditekan "start" untuk memulai. Nilai kadar air tertera pada layar, tekan tombol stop jika proses sudah selesai.

\section{Profil asam amino (AOAC 2005)}

Komposisi asam amino ditentukan dengan HPLC. Peralatan yang digunakan mempunyai spesifikasi Merek HPLC waters coorporation, USA. Kolom accQtag column (3,9x150 mm). Temperatur $37^{\circ} \mathrm{C}$. Fase gerak acetonitril 60\% - AccqTag Eluent A, sistem komposisi gradien. Laju alir 1,0 mLt per menit. Detektor fluorescense, Eksitasi $=250 \mathrm{~nm}$, emisi $=395 \mathrm{~nm}$. Volume penyuntikan $5 \mu \mathrm{L}$. Nama standar Amino acid standard produksi Thermo Scientific. Konsentrasi dihitung berdasarkan rumus:

$$
\text { Konsentrasi asam amino }=\frac{\text { luas area contoh }}{\text { luas area standar }} \times \frac{\mathrm{C} \times \mathrm{FP} \times \mathrm{BM} \times 100}{\text { bobot contoh (g) }}
$$

Keterangan :

$\mathrm{C}=$ konsentrasi standar asam amino

$\mathrm{FP} \quad=$ faktor pengenceran

$\mathrm{BM}=$ bobot molekul dari masing-masing asam amino

Data yang diperoleh kemudian dianalisis menggunakan Analisis sidik ragam atau
Analysis of Varians (ANOVA) dengan program SPSS 16.

\section{HASIL DAN PEMBAHASAN Nilai Organoleptik Terasi Rebon}

Terasi yang dihasilkan baik pada hari ke-8 maupun hari ke-32 semuanya dapat diterima oleh panelis (Tabel 1). Peningkatan nilai kesukaan organoleptik terjadi di hari ke-32 dari pada hari ke-8, hal ini disebabkan karena pada hari ke- 8 merupakan awal proses fermentasi sehingga komponen senyawa penyusun terasi belum selengkap atau sebanyak fermentasi hari ke-32. Fermentasi pada hari ke-32 yang sudah berlangsung menyebabkan peptida-peptida penyusun cita rasa yang dihasilkan selama fermentasi menjadi lebih banyak kualitas sehingga terasi menjadi lebih baik dan lebih disukai.

\section{Nilai pH Terasi}

Nilai pH terasi rebon berkisar antara 7,09 sampai 7,89. Nilai pH hari ke-8 $(7,47-7,89)$ cenderung lebih tinggi dibandingkan hari ke32 (7,09-7,69). Hasil uji statistik menunjukkan bahwa perbedaan yang nyata $(\mathrm{p}<0,05)$ pada beberapa perlakuan kecuali pada perlakuan $8,5 \%$ garam hari ke- 8 dan $2 \%$ garam hari ke-32 (Tabel 2). Trend penurunan $\mathrm{pH}$ ini sesuai penelitian Rianingsih et al. (2013) yang menyatakan bahwa penurunan $\mathrm{pH}$ diduga akibat dari proses dekomposisi protein yang menghasilkan senyawa basa volatil sehingga nilai $\mathrm{pH}$ tetap berada pada kisaran basa $(>7)$.

Penurunan $\mathrm{pH}$ dapat juga disebabkan dari bahan baku yang digunakan berupa rebon kering yang sebelumnya sudah terjadi proses penyimpanan yang cukup lama. Proses

Tabel 1 Nilai penerimaan konsumen pada produk terasi rebon pada konsentrasi garam yang berbeda dengan lama fermentasi

\begin{tabular}{ccc}
\hline \multirow{2}{*}{ Konsentrasi garam } & \multicolumn{2}{c}{ Nilai penerimaan konsumen } \\
\cline { 2 - 3 } & Hari ke-8 & Hari ke-32 \\
\hline $2 \%$ & $7,76 \leq \mu \leq 8,07$ & $7,97 \leq \mu \leq 8,32$ \\
$8,5 \%$ & $7,95 \leq \mu \leq 8,12$ & $7,91 \leq \mu \leq 8,22$ \\
$15 \%$ & $7,65 \leq \mu \leq 7,83$ & $7,62 \leq \mu \leq 7,90$ \\
\hline
\end{tabular}


Tabel 2 Nilai $\mathrm{pH}$, kadar protein, asam glutamat, dan kadar air terasi rebon pada konsentrasi garam yang berbeda dan lama fermentasi

\begin{tabular}{cccccc}
\hline Hari ke- & Kadar garam & $\mathrm{pH}$ & $\begin{array}{c}\text { Kadar Protein } \\
(\%)\end{array}$ & $\begin{array}{c}\text { Asam Glutamat } \\
(\%)\end{array}$ & Kadar Air (\%) \\
\hline 0 & $0 \%$ & $7,78 \pm 0,00$ & - & - & - \\
\hline \multirow{2}{*}{8} & $2 \%$ & $7,49 \pm 0,03^{\mathrm{c}}$ & $62,45 \pm 6,00^{\mathrm{a}}$ & $6,56 \pm 0,63^{\mathrm{a}}$ & $39,49 \pm 1,38^{\mathrm{cde}}$ \\
& $8,5 \%$ & $7,47 \pm 0,02^{\mathrm{cd}}$ & $57,88 \pm 2,42^{\mathrm{ab}}$ & $6,08 \pm 0,25^{\mathrm{ab}}$ & $38,04 \pm 0,59^{\mathrm{a}}$ \\
& $15 \%$ & $7,89 \pm 0,01^{\mathrm{a}}$ & $55,79 \pm 2,54 \mathrm{a}^{\mathrm{bc}}$ & $5,86 \pm 0,27^{\mathrm{abc}}$ & $36,12 \pm 2,02$ \\
\hline \multirow{2}{*}{32} & $2 \%$ & $7,41 \pm 0,07^{\text {cde }}$ & $47,14 \pm 0,20$ & $4,95 \pm 0,02$ & $36,91 \pm 0,60^{\mathrm{ab}}$ \\
& $8,5 \%$ & $7,47 \pm 0,02^{\mathrm{cd}}$ & - & - & $33,37 \pm 1,23^{\mathrm{c}}$ \\
& $15 \%$ & $7,69 \pm 0,07^{\mathrm{b}}$ & - & - & $37,37 \pm 1,20^{\mathrm{c}}$ \\
\hline
\end{tabular}

penyimpanan mempengaruhiproses enzimatis (autolisis) maupun bakteriologis dalam tubuh rebon. Moeljanto (1992) menyatakan bahwa fermentasi dapat dilakukan dengan bantuan enzim atau fermen yang berasal dari dalam tubuh ikan itu sendiri.

\section{Kadar Protein}

Kadar protein terasi rebon paling tinggi diperoleh pada konsentrasi $2 \%$ kemudian $8,5 \%$ dan paling sedikit adalah $15 \%$. Hasil uji statistik, nilai yang diperoleh dinyatakan tidak berbeda nyata $(p>0,05)$. Berdasarkan perlakuan lama waktu fermentasi, penurunan kadar protein mengalami penurunan. Terasi rebon $2 \%$ pada hari ke-32 menghasilkan ratarata kadar protein sebanyak $47,14 \% \pm 0,20$ (dry base) (Tabel 2). Nilai ini sedikit turun dibandingkan hari ke-8 pada konsentrasi garam yang sama. Kadar protein rebon menurut Nooryanti et al. (2005) adalah 16,2\%.

Perhitungan kadar protein hari ke-32 hanya dilakukan pada terasi dengan kadar garam terbaik yaitu 2\%. Tabel 2 menunjukkan bahwa kadar protein mengalami sedikit penurunan dari hari ke-8 sampai hari ke-32, hal ini disebabkan selama berlangsung proses fermentasi terjadi pemecahan senyawasenyawa protein yang komplek menjadi peptida-peptida yanglebih sederhana sehingga akan mempengaruhi jumlah total nitrogen dalam hal ini adalah kadar protein menjadi berkurang. Pemecahan senyawa protein komplek ini akan diikuti oleh pelepasan senyawa-senyawa lain. Menurut Nooryanti et al. (2010) selama proses fermentasi terasi, protein terhidrolisis menjadi turunannya yaitu proteolisis, peptone, peptidae, dan asam amino.

Menurut Peralta et al. (2019) fermentasi merupakan penguraian protein menjadi senyawa yang lebih sederhana (asam amino) dalam keadaan terkontrol melalui proses penguraian secara biologis atau semi biologis.

\section{Kadar Asam Glutamat}

Nilai glutamat mengalami penurunan walaupun secara statistik tidak terlihat adanya perbedaan yang nyata $(\mathrm{p}>0,05)$. Rebon dengan kadar garam 2\% menghasilkan kandungan asam glutamat yang tinggi yaitu 3,97\% (Tabel 2) sehingga proses fermentasi dapat berjalan secara optimum, sedangkan penambahan garam $8,5 \%$ dan $15 \%$ selama proses fermentasi menjadi asam amino dan peptida, kemudian asam-asam amino tersebut akan terurai menjadi komponen pembentuk cita rasa.

Menurut Jinap et al. 2010 perbedaan kadar glutamat belacan pada masing-masing brand salah satunya disebabkan oleh kadar air yang terdapat dalam campuran pasta belacan.

\section{Kadar Air}

Kadar air awal bahan baku rebon adalah $22,56 \% \pm 0,07$. Hasil uji kadar air terasi menunjukkan bahwa tidak berbeda nyata setelah terasi disimpan dari hari ke-8 sampai 
Tabel 3 Komposisi asam amino pada terasi rebon berdasarkan lama fermentasi

\begin{tabular}{llcc}
\hline No & \multicolumn{1}{c}{ Asam Amino } & $\begin{array}{c}\text { Rata-rata Terasi Rebon } \\
\text { (hari ke 8) }\end{array}$ & $\begin{array}{c}\text { Rata-rata Terasi Rebon } \\
\text { (hari ke32) }\end{array}$ \\
\hline 1 & L-asam aspartat & $3,28 \pm 0,06$ & $2,32 \pm 0,10$ \\
2 & L-serina & $1,15 \pm 0,40$ & $0,59 \pm 0,11$ \\
3 & L-asam glutamat & $4,91 \pm 0,25$ & $3.40 \pm 0,14$ \\
4 & Glisina & $1,94 \pm 0,27$ & $1,61 \pm 0,32$ \\
5 & L-histidina* & $1,03 \pm 0,54$ & $0,52 \pm 0,12$ \\
6 & L-agrinina $^{*}$ & $2,01 \pm 1,06$ & $0,99 \pm 0,25$ \\
7 & L-treonina & $1,62 \pm 0,52$ & $0,89 \pm 0,26$ \\
8 & L-alanina & $2,07 \pm 0,14$ & $1,58 \pm 0,07$ \\
9 & L-prolina & $1,38 \pm 0,25$ & $1,12 \pm 0,13$ \\
10 & L-sistina & $0,49 \pm 0,18$ & $0,32 \pm 0,01$ \\
11 & L-Tirosina & $1,33 \pm 0,33$ & $1,01 \pm 0,25$ \\
12 & L-Valina* & $1,92 \pm 0,39$ & $1,18 \pm 0,16$ \\
13 & L-Metionina & $1,17 \pm 0,33$ & $0,73 \pm 0,12$ \\
14 & L-Lisina HCL $^{*}$ & $3,04 \pm 0,15$ & $1,99 \pm 0,26$ \\
15 & L-isoleusina $^{*}$ & $1,70 \pm 0,29$ & $0,92 \pm 0,15$ \\
16 & L-Leusina $^{*}$ & $2,72 \pm 0,52$ & $1,33 \pm 0,19$ \\
17 & L-Phenilalanina $^{*}$ & $1,97 \pm 0,53$ & $1,22 \pm 0,29$ \\
\hline & Jumlah & $33,72 \pm 5,86$ & $21,72 \pm 2,40$ \\
\hline
\end{tabular}

Keterangan: *: asam amino essensial

hari ke-32. Kisaran kadar air hari ke-8 36,12\% $\pm 2,02-39,49 \% \pm 1,38$, sedangkan setelah disimpan sampai hari ke-32 kisarannya menjadi $36,91 \pm 0,60 \%-38,37 \pm 1,23 \%$. Nilai kadar terasi pada konsentrasi garam dan lama penyimpanan dapat dilihat pada Gambar 1.

Hasil uji statistik menunjukkan bahwa nilai kadar air hari ke-8 dan ke-32 tidak berbeda nyata. Adanya kadar air yang rendah menunjukkan bahwa proses fermentasi bisa berjalan dengan baik pada bahan baku rebon dan tidak terjadi kebusukan. Persentase kadar air yang terjadi dari hari ke-8 sampai hari ke32 akan mempengaruhi komposisi kimia yang lain misalnya kadar protein, kadar lemak, kadar karbohidrat, dan kadar abu.

\section{Profil Asam Amino}

Komposisi terbanyak asam amino adalah asam glutamat dan asam aspartat, Asam glutamat berperan penting dalam pembentukan rasa umami pada masakan lebih diterima panelis. Komposisi asam amino pada terasi rebon berdasarkan lama fermentasi dapat dilihat pada Tabel 3.

Komposisi terbanyak asam amino adalah asam glutamat dan asam aspartat, Asam glutamat berperan penting dalam pembentukan rasa umami pada masakan lebih diterima panelis. Penelitian Jinap et al. (2010), beberapa masakan yang ditambahkan sambal belacan dengan nilai asam glutamat lebih tinggi menunjukkan lebih diterima konsumen. Mouritsen et al. (2012), asam amino asapartat berkontribusi memberikan efek pada cita rasa produk rausu-konbu yang dihasilkan.

Jumlah total asam amino yang diperoleh pada hari ke-8 $(33,72 \% \pm 5,86)$ lebih banyak dibandingkan jumlah asam amino pada hari ke-32 $(21,72 \% \pm 2,40)$, hal ini menunjukkan bahwa setelah difermentasikan dengan waktu 
yang lebih lama asam amino yang dihasilkan terasi menjadi berkurang. Proses fermentasi berlangsung relatif lebih cepat sehingga pada saat pengamatan hari ke 32 asam amino yang dihasilkan sudah banyak terurai menjadi senyawa-senyawa lain.

\section{KESIMPULAN}

Konsentrasi garam 2\% menghasilkan kandungan asam glutamat tertinggi, sedangkan lama fermentasi hari ke-8 menghasilkan asam amino yang lebih banyak.

\section{DAFTAR PUSTAKA}

[AOAC] Association of Official Analytical Chemist. 2005. Official Methods of Analysis of The Association of Official Analytical Chemist. Arlington, Virginia (USA): Association of Official Analytical Chemists Inc.

[AOAC] Association of Official Analytical Chemist. 2007. Official Methods of Analysis of The Association of Official Analytical Chemist. Arlington, Virginia (USA): Association of Official Analytical Chemists Inc.

Balai Besar Riset Pengolahan Produk dan Bioteknologi Kelautan dan Perikanan. 2010. Mengenal Produk Fermentasi. http://bbrp2b.dkp.go.id (diakses 8 Januari 2012).

[BSN] Badan Standardisasi Nasional. 1995. Standar Nasional Indonesia No. 063731-1995. Prosedur Pengujian Asam Glutamat.http://websisni.bsn.go.id (diakses tanggal 16 November 2011).

[BSN] Badan Standardisasi Nasional. 2009. Standar Nasional Indonesia No. 012716-2009. Tentang Terasi Udang. http:// websisni.bsn.go.id (diakses tanggal 16 November 2011).

Jinap S, Ilya-Nur AR, Tang SC, Hajeb P,
Shahrim K, Khairunnisak M. 2010. Sensory attributes of dishes containing shrimp paste with different concentrations of glutamate and 5'-nucleotides. Appetite 55:238-244.

Moeljanto. 1992. Pengawetan dan Pengolahan Hasil Perikanan. Jakarta. Penebar Swadaya

Mouritsen O G, Lars Williams, Rasmus Bjerregard and Lars Duelund. 2010. Seaweeds for umami flavor in the New Nordic cuisine. Flavour 1:1-4.

Nooryantini S, Yuspihana F, Rita K. 2010. Kualitas terasi udang dengan suplementasi Pediococcus halophilus (FNCC-0033). Jurnal Hasil Perikanan 1:55-56.

Peralta EM, Hideo H, Daisuke W, Hisashi M. 2005. Antioxidative activity of philipine salt fermented shrimp and variation of its constituens during fermentation. Journal of Oleo Science 54(10):553-558.

Rianingsih L, Sakanti, Hervitri R, Sumardianto. 2013. Pengaruh konsentrasi garam dan lama fermentasi pada proses pengolahan terasi udang rebon (Acetes sp.) terhadap kandungan asam glutamat. Jurnal Pengolahan dan Bioteknologi Hasil Perikanan 2(2):(2013).

Shahidi F, Botta JR. 1994. Seafoods: Chesmistry, Processing, Technology and Quality. London: Blackie Academic and Profesional.

Susilowati A. 2010. Pengaruh aktivitas proteolitik Aspergillus sp. dalam perolehan asam-asam amino sebagai fraksi gurih melalui fermentasi garam pada kacang hijau (Phaseolus radiatus L.). Rubrik Teknologi Pangan 19(1):13-17.

Thapa N. 2002. Studies on microbial diversity associated with some fish products of the eastern himalayas. [thesis]. India: North Bengal University, Darjeeling. 